\title{
Pre-school Education Curriculum Thinking and Political Teaching Exploration - Heroes into Teaching
}

\author{
Houqiaohua $^{1, \mathrm{a}}$
}

\author{
${ }^{1}$ Aurora College, Baoshan District, shanghai, china \\ a754285859@qq.com
}

\begin{abstract}
summary Hero figure is the vanguard model of the times, is an important force to realize the prosperity and rejuvenation of the Chinese nation."hero" and "hero" spirit has rich connotation and educational value. Deeply interpret the "hero" characters and spirit, integrate them into pre-school education, and play the role of ideological education and subject education in the same direction.
\end{abstract}

Keywords: Hero, pre-school education, education

\section{学前教育学课程思政教学探索一英雄人物融入教学}

\author{
候乔桦 ${ }^{1, a}$
}

\author{
1 上海震旦职业学院，宝山区，上海，中国 \\ a754285859@qq.com
}

\section{摘要}

英雄人物是时代的先锋模范, 是实现中华民族繁荣复兴的重要力量, “英雄” 以及 “英雄” 精神有着丰富的内 涵和育人价值。深刻解读 “英雄” 人物与精神，将其融入学前教育中，发挥思想教育与学科教育同向育人的作 用。

关键词: 英雄, 学前教育, 育人

\section{1. “英雄”内涵}

《春秋繁露・爵国》中 “十人者曰豪, 百人者曰 杰, 千人者曰俊, 万人者曰英” , “英” 最早来表示才 智杰出, 才能出众的人。《正字通》曰: “尧、舜者, 天下之英也”，又如《资治通鉴》“况刘豫州王室之 胄, 《礼记・辨名记》“德过千人曰英”。“雄”指 勇武强壮, 常与雄鸟作比喻。汉以来 “英” 与 “雄” 才并列使用, 如王充《论衡》中 “案东文术、会稽吴 君高、周长生之辈, 位虽不至公卿, 诚能知囊㯻, 文 雅之英雄。”尤其在东汉末年人物志中频繁出现 “英 雄” 二字。“英雄” 成为固定的搭配常用于形容 “文 武兼备, 拥有文韬武略” 的稀有人才, 智慧才能超群 是 “英雄” 的最浅层次含义。” 除此之外, 中国古代 的 “英雄” 还不局限于男女、成败、地位, 如巾帼英 雄花木兰、西楚霸王项羽、一代天骄成吉思汗、薛仁 贵、卫青、霍去病等, 尤感慨于英雄的所做之事对于 人或者大众的意义，体现了中华民族 “悲天悯人” 仁
爱精神, 古人对 “英雄” 形象的描述也反映了中国人 独有的 “精气神”, 凡英豪者, 必有凌云之志, 气势 磅礴之势, 腹纳九州之量, 包藏四海之胸襟, 肩扛公 理, 横刀立马、解大众于倒悬……, 中国古代的英雄 不是对于 “力量”、“智慧” 的单一崇拜, 背后深藏 中国人对 “浩然之气”、“青云之志”、“不畏艰险” 个人品格的欣赏与追求。中国古代英雄是古代勤劳智 慧中国人民的缩影，饱含中国对仁爱、正义、勇敢地 追求与向往，是中国特有的文化特征。中国文化源远 流长, 经久不衰, 中华儿女 “英雄” 辈出, 在每个时 代成为照亮前行的星星。新中国成立以来，人们对“英 雄” 的理解更加全面，1949 年中国人民政治协商会 议第一次全体会议，毛泽东首次提出 “人民英雄” 的 概念。“人民英雄”肯定了人民在推动历史发展中的 决定力量, 符合马克思唯物史观。马克思主义认为英 雄来自于群众、为了群众、代表群众、引领群众, 是 人民群众中的先进分子和杰出代表, 脱离群众的英雄 将是孤家寡人; 而离开英雄人物号召引领的群众将是 
一盘散沙。“英雄” 是始终与人民在一起, 符合广大 人民的根本利益, 他代表人民, 并不脱离人民。中国 英雄是为人民和中华民族做出突出贡献的人民，从 1840 年到近现代，我们看到了 “大义凌然，英勇就 义” 的刘胡兰, 平凡岗位, 苦干实干发扬螺丝钉精神 的雷锋、“俯首甘为孺子牛” 的焦裕禄…… “英雄” 的内涵在建国以来得到最大程度的发展。今日, 我们 在习近平总书记的带领下依然发扬“英雄精神”，习 近平在颁发 “中国人民抗日战争胜利 70 周年” 纪念 章仪式上的讲话中指出: “今天, 中国正在发生日新 月异的变化, 我们比历史上任何时期都更加接近实现 中华民族伟大复兴的目标。实现我们的目标, 需要英 雄, 需要英雄精神。” 中国特色社会主义进入新时期 之际, “英雄” 文化的内涵得到进一步发展, 2019 年习近平在中华人民共和国国家勋章和国家荣誉称 号颁授仪式上提出, 要弘扬英雄模范身上展现的 “忠 诚”、“执着”、“朴实” 的鲜明品格。其中, 忠诚 就是对党和人民事业矢志不渝、百折不挠, 坚守一心 为民的理想信念; 执着是在党和人民最需要的地方冲 锋陷阵、顽强拼搏, 几十年如一日埋头苦干, 为国为 民奉献的志向坚定不移, 对事业的坚守无怨无悔, 为 民族复兴拼搏奋斗的赤子之心始终不改; 朴实是在平 凡的工作岗位上忘我工作、无私奉献, 不计个人得失, 舍小家顾大家，具有功成不必在我、功成必定有我的 崇高精神。习近平在新时代对英雄品格的深刻解读与 高度概括使 “英雄” 文化发展推向了新高度。总之, “英雄” 植根于中国五千年深厚的文化中, 拥有智慧 与才能, 坚守正义、团结最广大人民，活跃在在每个 中国发展的历史时期, 源源不断地为中国的发展贡献 力量, 是中华民族的代表。在信息爆炸、多元文化融 合的时代, 注重培养青少年提升个人辨别是非真假信 息能力, 树立正确价值观, 需要崇尚 “英雄” 学习 “英 雄” 榜样。“榜, 所以辅弓䋈”, 青少年教育需要一 个 “英雄” 的范式。

\section{2. “英雄” 事迹与教育}

为更好地弘扬 “英雄” 精神, 培养未来中国特色 社会主义接班人, 2018 年 4 月 27 日审议通过了《中 华人民共和国英雄烈士保护法》, 其中规定教育行政 部门、各级各类学校应当将英雄烈士事迹和精神纳入 教学内容。学校是教育的主要阵地, 教育的引导涉及 到 “培养什么样的人, 怎样培养人, 为谁培养人” 根 本问题。学校特别是教师应重视 “英雄” 教育, 积极 推进英雄事迹 “进教材”、“进课堂”、“进头脑”, 在各个学科中渗透 “英雄” 教育内容, 实现协同育人。 2016 年习近平在全国高校思想政治工作会议中强调 要把思想政治工作贯穿教育教学全过程, 实现全程育 人、全方位育人，坚持全员全过程全方位育人，把思 想价值引领贯穿教育教学全过程和各环节”, 各个学 科应该守好各自的渠。学前教育是对《学前教育学》 是学前教育专业中重要专业基础理论课。它开设时间 是大一第一学期, 包含教育观、儿童观、学前课程观 等至关重要的学前基础理论知识, 这门课程的学习形
成专业内学生的 “专业印象”, 是学习其他课程的“敲 门砖” 和 “基石”。“英雄人物” 与《学前教育学》 课程的结合是在响应国家 “立德树人” 的教育目标, 是在教育过程中将知识传授与价值引领相结合, 是在 “大思政” 背景下学前教育专业课程改革的探索, 有 利于学前专业学生树立正确的价值观, 促进未来幼儿 教育健康良性发展。

\section{3. “英雄” 事迹融入学前教育}

“英雄事迹” 教材、教材的融入首先要解决理念 问题, “英雄” 事迹精神的融入要与专业培养的目标 一致, 这就要求二者在价值观上要有呼应。例如, 习 近平曾强调, “革命传统教育要从娃娃抓起, 既注重 知识灌输, 又加强情感培育, 使红色基因渗进血液、 浸入心扉, 引导广大青少年树立正确的世界观、人生 观、价值观。”学前教师在面对教育对象一幼儿或者 育儿过程中, 要注意中国红色文化与中国精神的教 育, 这一点与教育部颁布 2012 年出台的《幼儿园教 师专业标准（试行）》中 “专业理念与师德” 的要求 相符合, 其中要求学前教师要贯彻党和国家教育方针 政策, 理解幼儿保教工作的意义。在幼儿、育儿教学 过程中注意了解中国学前教育发展的过程以及中国 学前教育家的在其发展过程中的尝试、革新、实践有 助于学前学生认同中国学前教育的专业性与独特性, 重视中国红色教育在幼儿教育中的传播。其次, “融 入” 问题要讲究方法。在罗仲尤、段丽、陈辉 “高校 专业课教师推进课程思政的实践逻辑”研究中提出教 师教学思想育人中要拥有三大核心能力 “ “挖掘、转 化、融入能力” , 教师要善于挖掘育人元素, 善于利 用育人资源, 进行学术、现实、实践的转化。由此, 英雄教育融入学前教育教学中, 要学会挖掘丰富的

“英雄” 素材, 善于利用学科资源进行转化, 注意 “适 度”、“适时”。

\section{1. “英雄” 内涵与职业价值引领}

《学前教育学》有一个章节主要讲述 “学前教 师”，章节的目标培养 “热爱学前教育事业, 具有职 业理想, 践行社会主义核心价值体系, 履行教师职业 道德规范” 的学前教师。然而学前教师教育对象低龄 化、劳动繁琐而冗杂让很多刚毕业的学前学生身心面 临巨大的压力。他们充满活力、斗志昂扬是学前专业 发展的新星, 然而进餐、盄洗、午睡、照顾幼儿哭 闹……也是需要他们亲力亲为一件一件要处理的工 作琐事。在繁杂、喧闹的学前工作中容易让人失去职 业的耐心, 忘记职业的初心, 职业倦急扑面而来。“人 民英雄”的概念是学前职业生涯中的一针强心剂, “英 雄” 不仅仅是冲锋陷阵、活跃在中国发展的最前沿, 坚守岗位, 依然能够影响大批的人和事, 英雄也是“平 凡的英雄”, 每一个为国家人民作出贡献的人都是“英 雄” 。将 “英雄” 的内涵融入职业理想中, 鼓舞学前 学生要勇于坚守, 做 “人民英雄”。 


\section{2. 讲好 “英雄” 故事与 “育儿”}

《幼儿园教育指导纲要 (试行)》划分幼儿园教 育内容为五大领域: 语言、社会、艺术、科学、体育。 在幼儿园“社会”领域教育中要培养幼儿的集体意识、 团体意识，激发幼儿爱集体、爱家乡、爱祖国的社会 情感。在社会领域中要求学前教师充分利用社会资 源,引导幼儿感受祖国文化的丰富和优秀。选取画面 感强 “英雄” 故事, 采用优美生动的语言, 采用通俗 易懂的方式给幼儿讲述 “英雄” 故事, 有助于引导幼 儿树立正确的价值观。开展以 “英雄”、“红色” 为 主题的绘本、主题墙活动, 学会用直观的方式 “讲述” 英雄故事, 增长幼师 “爱国” 育儿教育。

\section{3. “英雄” 情怀与当代大学生心理发展需求}

2016 年 2 月习近平赴江西看望慰问广大干部群 众时讲话: “中华民族是崇尚英雄、成就英雄、英雄 辈出的民族, 和平年代同样需要英雄情怀。” “英雄 情怀” 是对英雄事迹的铭记与敬仰。中华民族的伟大 复兴是一条艰苦奋斗之路, 需要前赴后继的力量, 这 条路上既有前辈们牺牲、汗水也需要现代青年人的接 力。活在信息大爆炸的青年人, 他们每天充斥着各种 各样的信息, 博人眼球的图片、脑洞大开的新闻、韵 律十足的音乐……应接不暇。信息数量不等价于信息 质量更不等价于人们更好的生活。相反, 虚实信息真 假难辨, 过度充斥让人无从选择。当代大学生学习、 生活娱乐有更多的选择, 关注当代大学生的心理需求 是教育值得考虑的事。当代大学生他们依然活力、热 情甚至有些冲动, 不同的是他们比其他时代更追求 “个性 “、“自由”、“价值”。他们也在释放自己 的精力, 期待找到自己的价值, 然而物质充裕, 内心 贵乏的青年人将精力贡献给了游戏、视频、甚至寻求 各种各样的娱乐中, 成为了游戏里的 “英雄” 、视频 里的 “键盘侠” 、生活里的 “怪咖”, 他们却自以为 找到了 “人生价值”。当今时代发展迅速, 我国比任 何一个时代都更需要英雄, 这个 “英雄” 是实实在在 能在专业领域发挥一己之力的人才。追求真正的 “英 雄”, 了解这个社会需要的 “英雄” 为大学生树立学 习的榜样。培养大学生 “英雄情怀” 有助于大学生在 专业学习中坚定信心, 担负社会责任。特别是在学前 知识教学中, 要有对专业以及专业前辈的恭敬之心, 强化学习态度。

\section{4. 做好 “英雄” 事迹宣传}

“英雄”事迹入教材的其中一个重点, 在于对“英 雄” 人物的宣传。查阅一些文献后发现, 目前 “英雄 “事迹的宣传主要存在两大问题: 英雄形象、事迹“眼 球化”; 英雄价值挖掘脱离当下现实。受到网络媒体 的影响, 一些 “英雄” 的宣传竟变成获取流量、博人 眼球的网络快文, 袋渎了 “英雄” 精神。还有一些 “英 雄” 宣传其采用的方式过于单一, 素材陈旧, 不易激 发 “英雄” 事迹与当代的共鸣。注意保证 “英雄” 事
迹的真实性, 挖掘 “英雄事迹” 的现实价值有助于还 原 “英雄” 精神。

\section{4. 结语}

“英雄” 不仅仅是一段故事, 更是是一种精神, 一种文化, 它植根于中国五千历史, 代表源远流长的 中国文化，也是实现中华民族伟大复兴的见证者和攻 坚力量, 他们是民族最闪亮的坐标。“英雄” 事迹融 入学前教学, 丰富教育内容, 更大发挥课程 “育人” 价值，培养热爱祖国、担负民族责任感的优秀学前教 师。

\section{项目基金}

本文为 2020 年 “上海市高校青年教师培养资 助计划” 重点推荐项目《英雄事迹融入教学, 强化青年学生责任一以学前教育学课程为例》 的阶段性成果之一。

\section{REFERENCES}

[1] Mu Zhihong. Study on the Use of Sichuan Red Cultural Resources in the Teaching of Cultural Life. Sichuan Normal University, 2019.

[2] Wang Jing. The "five-dimensional model" of pre-school education professional curriculum thinking and politics resource mining--take "Child Development Psychology" as an example.2021,37(01):59-64.

[3] Meng Xiangni. New Era Revolutionary Heroism Education Research. Shanghai Normal University, 2020.

[4] YV Huiyang." Thinking and Suggestions on the Teaching of Pre-school Education Courses in the Perspective of Curriculum Thoughts and Politics( J.) Science and Education Exchange (Earlier Issue), 2020 (05): 109-110.

[5] Wang Xi." Curriculum Thinking and Politics "Incorporating into the Graduate Curriculum System: Graduate Education Research, 2019 (04): 64-68 plus 75 .

[6] Mu Zhihong. Study on the Use of Sichuan Red Cultural Resources in the Teaching of Cultural Life. Sichuan Normal University, 2019.

[7] Wu Yan." The excavation and application of the educational elements under the background of curriculum thinking and politics reform-- take the Pre-school Education Policy and Regulation as an example Modernization of education,Education 2019, 6 (19): 90-91. 
[8] Tian Jingzheng. Study on the curriculum of kindergarten social field based on philosophy of life. Hunan Normal University, 2013.

[9] Xi Jinping's Speech at a Series of Events to Mark the 70th Anniversary of the Victory of the Chinese People's War of Resistance Against Japanese Aggression and the World Anti-Fascist War, Beijing: People's Press,2015, p.19.

[10] Zhang Yang. Learn heroic deeds and carry forward the spirit of heroism And the extraordinary heroism is embodied in the ordinary work. People's Daily, 2018-10-01.

[11] Opinions of the State Council of the CPC Central Committee on Strengthening and Improving the Ideological and Political Work of Colleges and Universities under the New Situation.

[12] During his research in Anhui Province, Xi stressed the need to fully implement the outline of the 13th Five-Year Plan to strengthen reform, innovation and create a new situation for development. People's Daily,2016-04-28

[13] Luo Zhongyu, Duan Li, Chen Hui. The Practical Logic of Theory of Curriculum Thought and Politics by Professional Teachers in Colleges and Universities, Introduction to Ideological Theory Education, 2019 (11): 138-143.

[14] Li Shenglan. Preschool Education. Shanghai: East China Normal Press,2016.8

[15] "The Department of Basic Education of the Ministry of Education Kindergarten Education Guidelines (Trial) Interpretationof the "C" Nanjing: Jiangsu Education Press,2001

[16] Han Yunbo, Ye Xiangyu. On the Five Faces of Hero Culture in the New Era: Chongqing Social Sciences, 2020 (10): 122-140.

[17] Chen Dan. Discussion on the Path of The Construction of The Course of "Pre-school Education" in Higher Vocational Education, Journal of Jinhua Vocational and Technical College, 2019, 19 (01): 20-24. 